\title{
Models for Development of an Innovation Network in Clusters
}

\section{Jacek Gancarczyk}

PhD, Faculty of Management and Social Communication, Jagiellonian University in Krakow, Poland. https://orcid.org/0000-0002-5636-1062

\section{Marta Najda-Janoszka}

$\mathrm{PhD}$ (habilitated), Faculty of Management and Social Communication, Jagiellonian University in Krakow, Poland. https://orcid.org/0000-0002-5040-7250

Submitted: 11.10 .2019 | Accepted: 16.01.2020

\section{Abstract}

Purpose: The purpose of this article is to present selected models for development of an innovation network in clusters from the perspective of network relations.

Design/methodology/approach: The argumentation draws upon the literature on the concept of the network and on the results of research of other authors related to the activity of companies in clusters. Findings: Hierarchical relations between the dominant company and suppliers using its technology offer limited possibilities of innovation creation. Such an influence on the position of the company is exerted by "producer networks" where the leading company defines the conditions of production and supply and provides technology. Discovering new knowledge and creating innovation usually requires heterarchical relations where the power and decision-making process are decentralised and managerial competences and skills are balanced and dispersed among network participants. This case is represented by "buyer networks" where the leading company formulates expectations for product characteristics and the subcontractor responds to these requirements using its own development and design solutions.

Research limitations/implications: The research is based on the theoretical literature on the concept of the network and on the results of empirical research of other authors related to the activity of companies in clusters.

Originality/value: The article broadens the area of research in the field of cluster and network relations as well as indicates the possibility of using this knowledge in entrepreneurs' decisions.

Keywords: innovation network, clusters, innovations.

JEL: M2, L26, 031

Correspondence address: Faculty of Management and Social Communication, Jagiellonian University in Krakow, Łojasiewicza 4, 30-348 Krakow, Poland; email: jacek.gancarczyk@uj.edu.pl.

Suggested Citation: Gancarczyk, J., \& Najda-Janoszka, M. (2020). Models for Development of an Innovation Network in Clusters. Problemy Zarządzania (Management Issues), 18(1), 179-192. https://doi.org/10.7172/1644-9584.87.8. 


\section{Modele rozwoju sieci innowacyjnej w klastrach}

\section{Streszczenie}

Cel: Celem niniejszego artykułu jest przedstawienie wybranych modeli rozwoju sieci innowacyjnej w klastrach z perspektywy relacji sieciowych.

Metodologia: Metodologia wraz z argumentowaniem bazują na literaturze przedmiotu dotyczącej koncepcji sieci oraz na wynikach badań innych autorów związanych z działalnością firm w klastrach.

Wyniki: Relacje hierarchiczne pomiędzy firmą dominującą a dostawcami korzystającymi z jej technologii oferują ograniczone możliwości tworzenia innowacji. Taki wpływ na pozycję firmy wywierają „sieci producentów", w których wiodąca firma określa warunki produkcji i dostaw oraz zapewnia technologię. Odkrywanie nowej wiedzy i tworzenie innowacji wymaga zwykle relacji heterarchicznych, w których władza i proces decyzyjny są zdecentralizowane, a kompetencje i umiejętności menedżerskie są wyważone i rozproszone wśród uczestników sieci. Taki przypadek prezentują „sieci kupujących”, w których wiodąca firma formułuje oczekiwania dotyczące cech produktu, a podwykonawca odpowiada na te wymagania, stosując własne rozwiązania w zakresie rozwoju i projektowania.

Ograniczenia badań i wnioskowania: Badania opierają się na teoretycznej literaturze przedmiotu w zakresie koncepcji sieci oraz na wynikach badań empirycznych innych autorów dotyczących działalności firm w klastrach.

Oryginalność: Artykuł poszerza obszar badań w zakresie koncepcji klastrów i relacji sieciowych, a także wskazuje na możliwość wykorzystania tej wiedzy w decyzjach przedsiębiorców.

Słowa kluczowe: sieć innowacyjna, klastry, innowacje.

\section{Introduction}

Network relations among organisations are treated as one of the structural characteristics of clusters and the basis of cluster competitiveness. Formal and informal interdependences among organisations in cluster concentrations ensure access to complementary resources and generate and accumulate knowledge that underpins innovation. In order to avoid isolation in access to external tangible and intangible resources, companies try to extend the scope of networks by establishing new relations. Competitiveness, innovation and new technologies are today the main sources of a strong market position. The activity of enterprises located in clusters affects the processes oriented towards a system of internal or external links. The processes focused on a network of relations within the cluster do not provide protection against the danger of isolation which causes negative externalities of the network. The processes based on the construction of external (international) links, associated with the relocation of selected elements of the value chain, allow isolation to be avoided and positive effects of the network to be produced (Gancarczyk \& Gancarczyk, 2011, 2018).

The aim of the article is to present selected models for development of an innovation network in clusters based on a review of empirical research, as well as to indicate the possibility of using this knowledge in entrepreneurs' decisions. The paper presents the assumptions of the network approach to enterprises in clusters, taking into account the evolution from local networks 
to international networks. The analysis and conclusion was based on the literature on the concept of the network and on the results of empirical research of other authors related to the activity of companies in clusters. Network connections condition the creation and spread of knowledge, hence they are treated as the basis of competitiveness. The article uses literature studies in the field of cluster concepts and empirical studies on evolution within the considered phenomenon.

\section{The Concepts and Meaning of Clusters and Innovation Networks}

Clusters are defined as geographic concentrations of enterprises operating in one sector or a limited number of adjacent sectors, in mutual dependences and relationships with business environment organisations (Porter, 1998). It is now accepted that the term "cluster" encompasses elements previously defined as industrial areas or districts, industry-specific production systems or specialised industrial agglomerations (Vanhaverbeke, 2001). The most competitive clusters are usually based on advanced forms of cooperation which include not only vertical relations (supplier-customer) but also horizontal links (among companies in the same sector, e.g. in the field of marketing, research and development (R\&D), supply), and relationships with business environment institutions. It should be pointed out, however, that even a group of the most competitive clusters is differentiated by configurations of network relations, namely the degree of involvement of business environment institutions, the role of large and small enterprises, the level of internal competition, and the nature of cooperative relations (e.g. the predominance of long- or short-term relations). For example, Italian clusters are marked by strong links between enterprises and business environment institutions (e.g. local government) and longterm, formalised cooperation rules such as active industrial associations and chambers of commerce. On the other hand, clusters in the USA are viewed as more oriented towards competition and relations primarily between companies, with a weaker emphasis on business environment institutions and with a predominance of short-term contractual relationships (Bathelt, 2001). Research studies contain various typologies of clusters, depending on the adopted criteria. The aspects that are most often taken into account include: the size of enterprises, degree of development and structure, degree of openness to innovation, knowledge and new technologies, life cycle, type of core business, historical and cultural background, competitive position in the market, position in the consumer value chain, degree of maturity.

The related literature emphasises various attributes that characterise this form of industry organisation (Vanhaverbeke, 2001). The term "cluster" is used in the following meanings:

Problemy Zarządzania - Management Issues, vol. 18, no. 1(87), 2020 
- geographic concentration of companies in adjacent sectors - a phenomenon in the real sphere, subject to empirical research and measurement (A. Marshall at the end of the 19th century; researchers studying the so-called Italian districts in the central and north-eastern regions of Italy: G. Becattini, A. Bagnasco, M. Bellandi, S. Brusco, G. Garofoli; American researchers: M. Piore, I C. Sabel, P. Krugman, M.E. Porter, A. Saxenian, A. Markusen, M. Storper, A. Scott);

- a form of industry organisation based on the spatial concentration of companies operating in adjacent sectors (D. Maillat, M.E. Porter, S. Klepper, A. Markusen, M. Storper, F. Pyke, W. Sengenberger);

- a concept explaining the aforementioned form of spatial organisation of industry - its attributes and causes of competitiveness.

An innovation network is organised cooperation between companies, aimed at creating innovation, and thus a competitive advantage of the entire network and the companies operating within it (European Commission, 2002). Usually, the following network attributes are indicated (Hakansson \& Snehota, 1989; Jarillo, 2011; Johannisson, 1998; Pyke \& Sengenberger, 1992; Saxenian, 2000, 2007; Czakon, 2011; Soda, Usai, \& Zaheer, 2004; Cegerra-Navarro, 2007; Najda-Janoszka, 2016):

- cooperative and competitive as well as formal or informal nature of dependences;

- relative permanence (a long-term relation) associated with the ability to evolve and change;

- emergence and development based on conscious and planned, hierarchical coordination (strategic networks that a company consciously builds) and/or spontaneous and non-hierarchical coordination (networks emerge from the market relations of companies rather than in a way intentionally planned by leaders).

\begin{tabular}{|l|l|}
\hline \multicolumn{1}{|c|}{ Concept } & \multicolumn{1}{c|}{ Meaning } \\
\hline Cluster & $\begin{array}{l}\text { A geographic concentration of interdependent firms within the same or } \\
\text { adjacent sectors }\end{array}$ \\
\hline $\begin{array}{l}\text { Innovation } \\
\text { network }\end{array}$ & $\begin{array}{l}\text { Organised cooperation between firms, stimulated by trust, norms and } \\
\text { conventions that encourage firms' innovation activity }\end{array}$ \\
\hline
\end{tabular}

Tab. 1. Cluster versus innovation network. Source: Based on European Commission (2002). Observatory of European SMEs, 3, 12-13, Brussels.

Participation in networks involves both benefits and threats. Benefits include:

- Access to partners' complementary resources and skills, resulting in the development of knowledge and innovation.

- Reduction of transaction costs (costs of market transactions, one-off costs, and costs of transactions within companies). 
- Opportunity to specialise and focus on key competences (those needed from outside the area of competence and specialisation are acquired from cooperating organisations).

- Opportunity to establish technological standards (through the influence of buyers on subcontractors, the influence of technology suppliers on companies buying this technology).

- Reduction of uncertainty (trust in partners, knowledge of reputation and operating standards of long-term partners).

- Increased flexibility and speed of operation (e.g. the possibility of smooth - because based on mutual adaptation - implementation of projects exceeding the capabilities of a single company).

Potential threats ensuing from the participation in a network include:

- Increased costs of network coordination (instead of carrying out an activity within the company's own organisational structure, it is necessary to develop the ability to coordinate a group of external entities to implement a specific project).

- Restricted market mechanism in the selection of business partners and technologies (a habit and costs of changing a long-term partner lead to the consolidation of relations, sometimes contrary to economic calculation and other benefits of switching suppliers or buyers).

- "Lock-in" (pitfall) - a dependence trap leading to a closure to development (in particular when it comes to the technology of a product or service; it results from an unfavourable relation due to the connection of the purchased good with complementary goods - we always buy from the same, although relatively expensive, supplier because more maintenance services are offered for this supplier's product and the product works better with more related goods).

- "Leak" of business information (subcontractors taking over the ordering company's market).

- Opportunism of partners (striving to pursue one's own interest using deception; concealing information, distorting it, fraud).

The benefits generated by networks include primarily low costs of concluding and performing market contracts (low transaction costs) and the development of specialist knowledge that is a source of innovation (Saxenian, 2000; Gancarczyk, 2017). This is determined by the specificity of the dissemination of information and knowledge. Information as a set of structured data is relatively simple to copy and transfer to another organisation, hence it can be diffused passively based on staff fluctuations or market contracts. Knowledge, which means the ability to use information, is often informal, implicit in competences and relationships among employees of a particular company that are difficult to copy and transfer to another organisational environment (Nonaka, 1991; Maskell \& Malmberg, 1999; Gertler, 2007). The permeation of knowledge to another company requires deeper and lasting relationships that occur in the conditions of network 
dependences (Molina-Morales \& Martínez-Fernández, 2006). By cooperating in network dependences, companies gain access to diverse resource and competence potential, making it possible for them to expand the scope of activity beyond the narrow boundaries of current activities. However, it should be borne in mind that innovation is co-created in parallel with individual network participants competing for their share of the generated value.

Business practice indicates that new value creation through the implementation of innovation is not at all tantamount to income generation by the value creators. This is because in order to make a profit, it is necessary to retain the entirety of created value or such its part that exceeds the costs incurred to generate it. This, in turn, is not an easy task because the specificity of innovations implemented, for example, in the services sector (innovations obtained from suppliers, innovations not subject to patent protection, product innovations susceptible to imitation) makes the retention of innovation value a particularly difficult challenge for companies. Therefore, if a new value is co-created within a variety of cooperative constellations, this significantly increases the complexity of the problem of retaining the generated value (Najda-Janoszka, 2015). The results of observation of multilateral cooperation indicate that the dominant share in the jointly created value does not necessarily translate into its retention proportionally to the contribution made (Najda-Janoszka, 2013). The key is for companies to co-create innovation with other network organisations and to be able to effectively retain the new value created jointly.

\section{Selected Models of Innovation Networks in Clusters}

Various models of innovation networks have been extensively and comprehensively described in the literature on clusters. Markusen (1996) distinguished the following four types of network connections in clusters, which connections can be treated as models of innovation networks (Gancarczyk, 2010, 2015). Network relations are described by the following factors: the nature of companies, the type of contracts between them, competition tools and the dominant type of innovation, the nature of human resources, access to financing infrastructure and business services (Table 2). The effect of the specific characteristics of these factors is the development prospects for the entire network.

An innovation network in the Marshallian (Italian) industrial district (cluster) is based on small and medium-sized enterprises that remain in long-term cooperative relations and competitive relations in the process of product production and development. Product innovation is the dominant type of innovation in this case (Figure 1).

https://doi.org/10.7172/1644-9584.87.8 


\begin{tabular}{|c|c|c|c|c|}
\hline $\begin{array}{c}\text { District (cluster) } \\
\text { type }\end{array}$ & $\begin{array}{l}\text { Marshallian industrial } \\
\text { district (Italian) }\end{array}$ & $\begin{array}{l}\text { "Hub-and-spokes" } \\
\text { district }\end{array}$ & "Satellite" platform district & $\begin{array}{c}\text { State-anchored industrial } \\
\text { district }\end{array}$ \\
\hline $\begin{array}{l}\text { Nature of } \\
\text { companies }\end{array}$ & $\begin{array}{l}\text { Small and medium-sized } \\
\text { enterprises (SMEs), local } \\
\text { owners }\end{array}$ & $\begin{array}{l}\text { One or several large vertically } \\
\text { integrated companies }\end{array}$ & $\begin{array}{l}\text { Large companies with offices } \\
\text { outside the district and owners } \\
\text { from outside the district }\end{array}$ & $\begin{array}{l}\text { One or several public } \\
\text { institutions }\end{array}$ \\
\hline $\begin{array}{l}\text { Type of } \\
\text { contracts }\end{array}$ & $\begin{array}{l}\text { Strong exchange between } \\
\text { suppliers and customers } \\
\text { within the district, long-term } \\
\text { contracts }\end{array}$ & $\begin{array}{l}\text { Strong exchange between } \\
\text { dominant companies and } \\
\text { suppliers within the district, } \\
\text { long-term contracts; intense } \\
\text { cooperation and relationships } \\
\text { between companies from } \\
\text { outside the district }\end{array}$ & $\begin{array}{l}\text { Poor exchange between } \\
\text { suppliers and customers } \\
\text { within the district, no long- } \\
\text { term relationships with local } \\
\text { suppliers, intense cooperation } \\
\text { with companies from outside } \\
\text { the district, especially with } \\
\text { parent branches }\end{array}$ & $\begin{array}{l}\text { Low turnover of local } \\
\text { companies, exchange within the } \\
\text { region limited to institutions } \\
\text { and their suppliers, short-term } \\
\text { contracts }\end{array}$ \\
\hline $\begin{array}{l}\text { Competition } \\
\text { tools (type of } \\
\text { innovation) }\end{array}$ & $\begin{array}{l}\text { Differentiation (product } \\
\text { innovation) }\end{array}$ & $\begin{array}{l}\text { Economies of scale (process } \\
\text { innovation) }\end{array}$ & $\begin{array}{l}\text { Economies of scale } \\
\text { (management innovation) }\end{array}$ & $\begin{array}{l}\text { Economies of scale in the } \\
\text { public sector. It depends on the } \\
\text { type of dominant organisation } \\
\text { (small and medium-sized } \\
\text { enterprises or a large company } \\
\text { based in the cluster and small } \\
\text { subcontractors or a branch of } \\
\text { the company based outside the } \\
\text { cluster) }\end{array}$ \\
\hline $\begin{array}{l}\text { Human } \\
\text { resources }\end{array}$ & $\begin{array}{l}\text { Strong staff exchange } \\
\text { between suppliers and } \\
\text { customers within the } \\
\text { district, a large proportion } \\
\text { of employees involved in } \\
\text { designing and innovation, } \\
\text { employees attached to the } \\
\text { district and not to companies }\end{array}$ & $\begin{array}{l}\text { Poor staff exchange between } \\
\text { a large company and suppliers, } \\
\text { a big proportion of less } \\
\text { qualified employees, employees } \\
\text { attached first to the large } \\
\text { company, then to the district, } \\
\text { then to a small company }\end{array}$ & $\begin{array}{l}\text { Employees attached to } \\
\text { the company rather than } \\
\text { the district, migrations of } \\
\text { managerial staff to and from } \\
\text { the district, poor migrations of } \\
\text { low-skilled workers }\end{array}$ & $\begin{array}{l}\text { Moderate staff exchange } \\
\text { between suppliers and } \\
\text { customers, predominance of } \\
\text { officials and professionals, } \\
\text { employees first attached to } \\
\text { institutions, then to the district, } \\
\text { and finally to small companies }\end{array}$ \\
\hline
\end{tabular}


Tab. 1. cont.

\begin{tabular}{|l|l|l|l|l|}
\hline $\begin{array}{l}\text { District (cluster) } \\
\text { type }\end{array}$ & \multicolumn{1}{|c|}{$\begin{array}{c}\text { Marshallian industrial } \\
\text { district (Italian) }\end{array}$} & \multicolumn{1}{|c|}{$\begin{array}{c}\text { "Hub-and-spokes" } \\
\text { district }\end{array}$} & "Satellite" platform district & \multicolumn{1}{|c|}{$\begin{array}{c}\text { State-anchored industrial } \\
\text { district }\end{array}$} \\
\hline $\begin{array}{l}\text { Risk-sharing, } \\
\text { innovation and } \\
\text { stabilisation } \\
\text { infrastructure }\end{array}$ & $\begin{array}{l}\text { Strong mechanisms; sources } \\
\text { of financing, technical } \\
\text { support and business services } \\
\text { outside companies but inside } \\
\text { the district }\end{array}$ & $\begin{array}{l}\text { No mechanisms; business } \\
\text { services, sources of financing } \\
\text { and technical support } \\
\text { dominated by large companies }\end{array}$ & $\begin{array}{l}\text { No mechanisms; sources of } \\
\text { financing, technical support and } \\
\text { business services come from } \\
\text { outside the district }\end{array}$ & $\begin{array}{l}\text { No specialised sources of } \\
\text { financing, technical support or } \\
\text { business services }\end{array}$ \\
\hline $\begin{array}{l}\text { The role of local } \\
\text { government }\end{array}$ & Strong & Weak & Weak & Weak \\
\hline $\begin{array}{l}\text { The role } \\
\text { of national } \\
\text { government }\end{array}$ & Moderate & Strong public involvement & Strong role of the government & $\begin{array}{l}\text { Strong involvement of public } \\
\text { finances }\end{array}$ \\
\hline $\begin{array}{l}\text { Investment } \\
\text { Within the district, based on } \\
\text { investment capital within the } \\
\text { district }\end{array}$ & $\begin{array}{l}\text { Within the district but of } \\
\text { supra-local significance }\end{array}$ & $\begin{array}{l}\text { Outside the district, no } \\
\text { investment capital within the } \\
\text { district }\end{array}$ & $\begin{array}{l}\text { At the government level, no } \\
\text { investment capital within the } \\
\text { district }\end{array}$ \\
\hline $\begin{array}{l}\text { Development } \\
\text { prospects for the } \\
\text { region }\end{array}$ & $\begin{array}{l}\text { Durable, based on the } \\
\text { strength of local companies, } \\
\text { knowledge, innovation, and } \\
\text { investment decisions taken } \\
\text { within the district }\end{array}$ & $\begin{array}{l}\text { Durable, based on the strength } \\
\text { of large companies as well as } \\
\text { on knowledge, innovation, and } \\
\text { investment decisions taken } \\
\text { within the district }\end{array}$ & $\begin{array}{l}\text { Impermanent, dependent on } \\
\text { knowledge, innovation and } \\
\text { investment decisions taken } \\
\text { outside the district }\end{array}$ & $\begin{array}{l}\text { Impermanent, dependent on } \\
\text { knowledge, innovation and } \\
\text { investment decisions taken } \\
\text { outside the district }\end{array}$ \\
\hline
\end{tabular}

. Characteristics of an innovation network in clusters. Source: Based on M. Gancarczyk (2015). Enterprise-and industry-level drivers of cluster evolution and their outcomes for clusters in developed and less developed countries. European Planning Studies, 23(10); A. Markusen (1996). Sticky Places in Slippery Space: A Typology of Industrial Districts. Economic Geography, 72(3). 


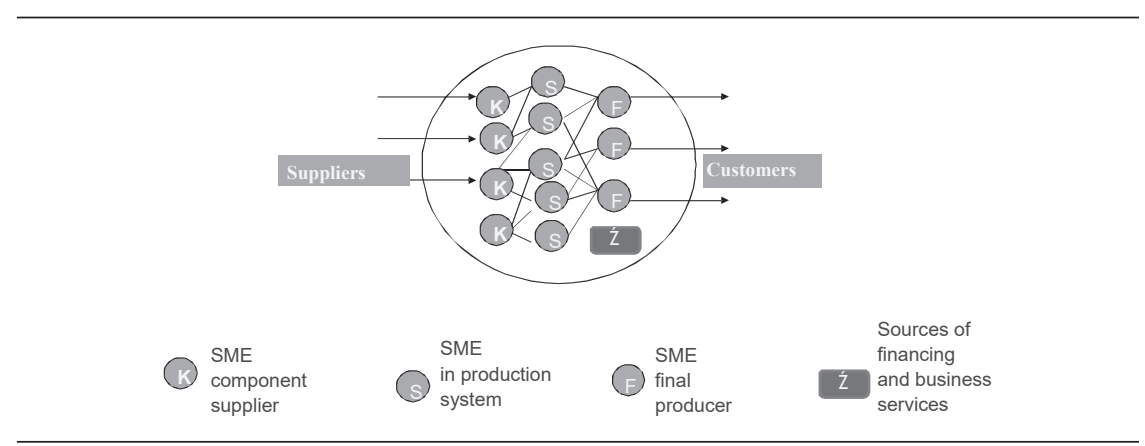

Fig. 1. Innovation network in the Marshallian (Italian) industrial district; product innovation. Source: Based on A. Markusen (1996). Sticky Places in Slippery Space: A Typology of Industrial Districts. Economic Geography, 72(3), 293-313.

An innovation network in the "hub-and-spokes" district consists of one or several large companies cooperating in the production process with a group of smaller subcontractors under long-term contracts. This network mainly generates process innovations aimed at reducing costs (Figure 2).

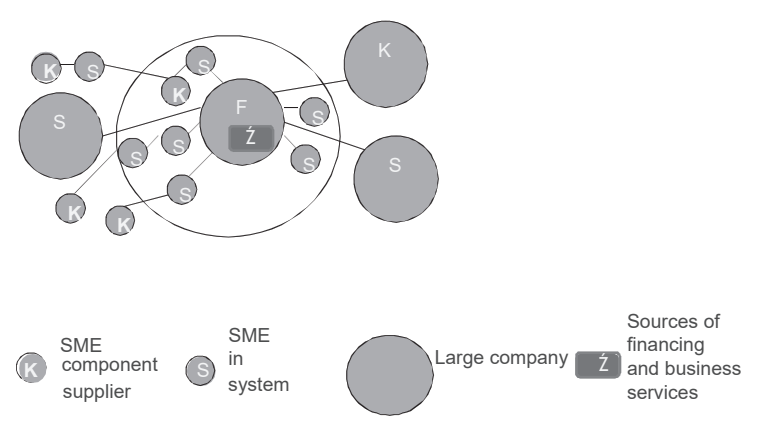

Fig. 2. Innovation network in the "hub-and-spokes" district; process innovation. Source: Based on A. Markusen (1996). Sticky Places in Slippery Space: A Typology of Industrial Districts. Economic Geography, 72(3), 293-313.

An innovation network in the "satellite" platform district consists of branches of large companies that do not develop cooperative relations with district companies in the production process but maintain strong links with branches, suppliers and customers of parent companies from outside the district. Local companies can provide support services (e.g. transport, renovation and construction services) and links with them are relatively weaker and less durable than in the case of the Marshallian (Italian) or "hub-andspokes" network. Management innovations (organisational and marketing innovations) predominate here as weak links with local subcontractors in 
the product production or service delivery process limit the possibilities for local companies to transfer and absorb technology and, consequently, also to generate technological innovations in such networks (Figure 3).
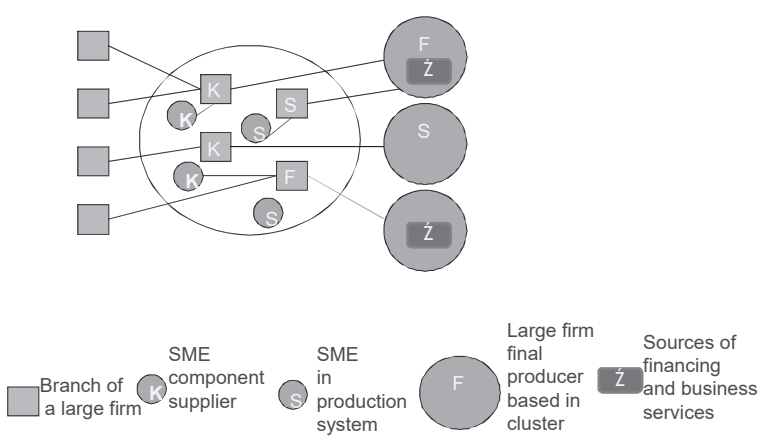

Fig. 3. Innovation network in the "satellite" platform district; management innovation. Source: Based on A. Markusen (1996). Sticky Places in Slippery Space: A Typology of Industrial Districts. Economic Geography, 72(3), 293-313.

An innovation network in the "state-anchored" industrial district consists of a public institution that can be, for example, a state-owned company, a university, a hospital or a military base and can take the organisational form of one of the above-described districts or be a combination of these forms. In this network, the dominant type of innovation depends on the network structure. If it is a technology park gathering small and medium-sized entities in equal and relatively stable cooperative relations, the Marshallian/ Italian district structure (product innovation) can be assumed to exist. If the network centre is a state-owned company based in the district, the structure resembles "hub-and-spokes" (process innovation) while in the case of a branch of a state-owned company as the network centre, we deal with the "satellite" structure (management innovation) (Figure 4).

In the case of the Marshallian (Italian) industrial district and the "huband-spokes" district, the prospects for development and generation of innovation within the network are permanent because they are founded on the strength of local companies and long-term dependences among them. Sustainable development and competitive advantage of a particular region also rests upon the location of a centre of investment decisions, technological know-how (research and development/R\&D department), value chain coordination and marketing within its territory. Prospects for the develop ment of networks based on "satellite" and "state-anchored" districts should be considered relatively impermanent. They most commonly emerge as a result of location decisions of large entities that seek savings on production costs ("satellite" district) or public authorities seeking to stimulate the 

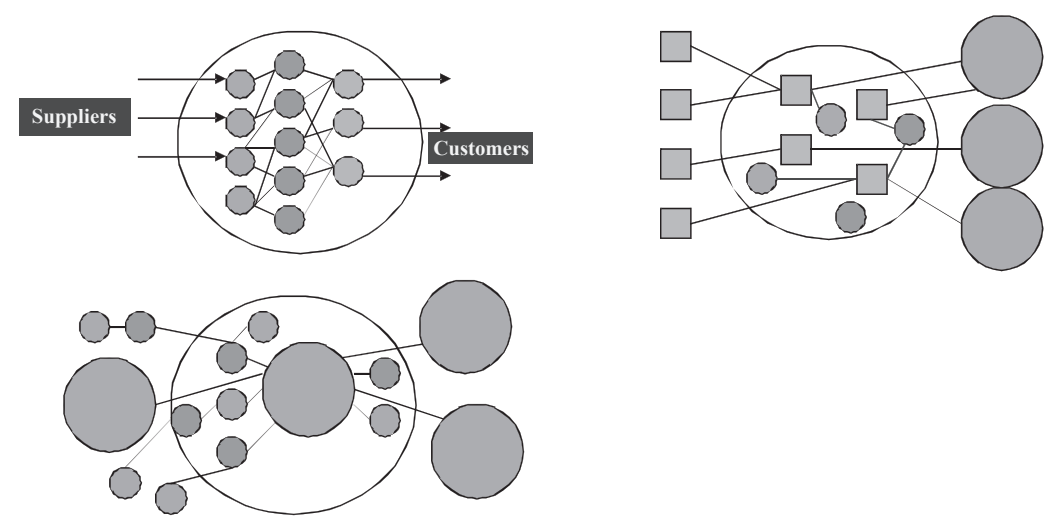

Fig. 4. Innovation network in the "state-anchored" industrial district; the type of innovation depends on the type of dominating organisations in the cluster. Source: Based on A. Markusen (1996). Sticky Places in Slippery Space: A Typology of Industrial Districts. Economic Geography, 72(3), 293-313.

development of a given region by establishing universities, military bases, technology parks or a state-owned company ("state-anchored" district). The investment decision centre then remains outside the district, which makes the region dependent on the decisions of management boards of large companies or the state. Research and development units in a satellite district are also most frequently located outside the branch. As a consequence, local companies only absorb management innovations (organisational innovations and management patterns). The problem of these two forms of industry organisation lies in the relatively weak embeddedness of links among company branches or public investment in the local environment, which prevents or hinders learning and increasing the competitiveness of cooperating suppliers. In the event of a crisis of the state finance or changes in the strategy of a large company, a withdrawal or reduction of investment poses a structural threat to the entire network and the local economy. There are, however, cases of embedded branches that locally establish links in the production process, thereby bringing the satellite network closer to the "hub-and-spokes" solution.

\section{Conclusion}

Individual companies in a cluster network perform a variety of roles. They include, for example:

a) small and medium-sized subcontractors in the product or service production process,

b) companies specialised in a specific service or production of a component, 
c) "network leaders" that act as the ordering party in relation to small businesses (subcontractors) and coordinate the entire value chain of a product or service,

d) "system integrators", service, including advisory and consulting, companies supplying logistics and production system design for manufacturing companies,

e) branches of large corporations, being a link between the cluster network and the international environment, especially as regards access to foreign markets and distribution channels.

The hierarchical or heterarchical type of network matters when it comes to the type and degree of radicalness of innovation. Hierarchical relations between the dominant company and suppliers or distributors using its technology offer limited possibilities of innovation creation (Chesbrough, 2003; Humphrey \& Schmitz, 2004; Lorentzen, 2008; de Propris, Menghinello, \& Sugden, 2008; Wall \& van der Knaap, 2011). Such an influence on the position of the company is exerted by "producer networks" where the leading company defines the conditions of production and supply and provides technology (Pavlínek, 2012; Rugraf, 2010; Sornn-Friese \& Sørensen, 2005; Gancarczyk, Gancarczyk, \& Bohatkiewicz, 2017). The work organisation in such cooperative relations is based on instructions, orders and prohibitions, unilateral technology transfer, limited decision-making possibilities and employee creativity (Lorenz, 2011). Paradoxically, despite their involvement in global production networks, companies (suppliers) then fall into the "lock-in" trap as regards development as part of routine, specialised and standardised operations. Discovering new knowledge and creating innovation usually requires heterarchical relations where the power and decision-making process are decentralised and managerial competences and skills are balanced and dispersed among network participants (Saxenian, 2007; Lam, 2007; de Propris, Menghinello, \& Sugden, 2008; Wall \& van der Knaap, 2011). This case is represented by "buyer networks" where the leading company formulates expectations for product characteristics and the subcontractor responds to these requirements using its own development and design solutions. Suppliers refine their processes by using the advice and technical support of buyers (Winter, 2010; Gereffi, Humphrey, \& Sturgeon, 2005). The work organisation is then characterised by decentralisation of relations, joint development of technology, complexity of tasks, significant decision-making and employee creativity possibilities (Lorenz, 2011).

The type of generated innovation is linked to the degree of diversity of network participants. A composition that is diversified in terms of entities and industries, where both customers and suppliers are present, is typical for the phase of network development termed "diversity" (March, 1991; Glückler, 2007) and stimulates the emergence of radical and product innovation (de Propris, 2002; Partanen, Chetty, \& Rajala, 2011]. The network development phase referred to as "selection" is marked by the similarity 
and industry specialisation of participants that principally create incremental and process innovations based on connections with suppliers.

\section{Acknowledgements}

This research received no funds.

\section{References}

Bathelt, H. (2001). Regional competence and economic recovery: Divergent growth paths in Boston's high technology economy. Entrepreneurship \& Regional Development, 13(4).

Cegerra-Navarro, J.G. (2007). Linking exploration with exploitation through relationships memory. Journal of Small Business Management, 45(3).

Chesbrough, H. (2003). Open innovation: The new imperative for creating and profiting from technology. Boston: Harvard Business School Press.

Czakon, W. (2011). Paradygmat sieciowy w naukach o zarządzaniu. Przeglad Organizacji, (11).

European Commission. (2002). Observatory of European SMEs, (3). Brussels.

Gancarczyk, M. (2010). Model schyłku i odrodzenia klastrów. Gospodarka Narodowa, (3).

Gancarczyk, M. (2015). Enterprise- and industry-level drivers of cluster evolution and their outcomes for clusters in developed and less developed countries. European Planning Studies, 23(10).

Gancarczyk, M. (2017). The process of SME growth. Integrating the resource-based and transaction cost approaches. Kraków: Jagiellonian University Press.

Gancarczyk, M., \& Gancarczyk, J. (2011). Wzrost i internacjonalizacja przedsiębiorstw w klastrach. Organizacja i Kierowanie, 3(146).

Gancarczyk, M., Gancarczyk, J., \& Bohatkiewicz, J. (2017). SMEs in modular value chains - perspectives for innovativeness and growth. Entrepreneurial Business and Economics Review, 5(3).

Gancarczyk, M., \& Gancarczyk, J. (2018). Proactive international strategies of cluster SMEs. European Management Journal, 36(1).

Gereffi, G., Humphrey, J., \& Sturgeon, T. (2005). The governance of global value chains. Review of International Political Economy, 12(1).

Gertler, M.S. (2007). Tacit knowledge in production networks: how important is geography? In K.R. Polenske (Ed.), The economic geography of innovation. Cambridge, UK: Cambridge University Press.

Glückler, J. (2007). Economic geography and the evolution of networks. Journal of Economic Geography, 7(5).

Hakansson, H., \& Snehota, I. (1989). No business in an island: The network concept of business strategy. Scandinavian Journal of Management, 5(3).

Humphrey, J., \& Schmitz, H. (2004). Governance in global value chains. In H. Schmitz (Ed.), Local enterprises in the global economy. Cheltenham: Edward Elgar Publishing.

Jarillo, J.C. (2011). Strategic networks: Creating the borderless organization. New York: Routledge.

Johannisson, B. (1998). Personal networks in emerging knowledge-based firms: Spatial and functional patterns. Entrepreneurship \& Regional Development, 10(4).

Lam, A. (2007). Multinationals and transnational social space for learning: Knowledge creation and transfer through global R\&D networks. In K.R. Polenske (Ed.), The economic geography of innovation. Cambridge, UK: Cambridge University Press.

Lorentzen, A. (2008). Knowledge networks in local and global space. Entrepreneurship \& Regional Development, 20(6).

Problemy Zarządzania - Management Issues, vol. 18, no. 1(87), 2020 
Lorenz, E. (2011). Regional learning dynamics and systems of education and training: a European comparison. Journal of the Knowledge Economy, 2(4).

March, J.G. (1991). Exploration and exploitation in organizational learning. Organization Science, 2(1).

Markusen, A. (1996). Sticky places in slippery space: A typology of industrial districts. Economic Geography, 72(3).

Maskell, P., \& Malmberg, A. (1999). Localised learning and industrial competitiveness. Cambridge Journal of Economics, 23(2).

Molina-Morales, X., \& Martínez-Fernández, M.T. (2006). Industrial clusters: Something more than a neighbourhood. Entrepreneurship \& Regional Development, 18(6).

Najda-Janoszka, M. (2016). Dynamic capability-based approach to value capture. Kraków: Jagiellonian University Press.

Najda-Janoszka, M. (2013). Innovative activity of small tourist enterprises - Cooperation with local institutional partners. Journal of Entrepreneurship, Management and Innovation, 9(1).

Najda-Janoszka, M. (2015). Problem zatrzymywania wartości przez MŚP - stadium przypadku działalności podwykonawczej. Marketing i Rynek, (9).

Nonaka, I. (1991). The knowledge creating company. Harvard Business Review, (69).

Partanen, J., Chetty, S.K., \& Rajala, A. (2011). Innovation types and network relationships. Entrepreneurship Theory \& Practice, 38(5).

Pavlínek, P. (2012). The internationalization of corporate R\&D and the automotive industry R\&D of East-Central Europe. Economic Geography, 88(3).

Porter, M.E. (1998). Clusters and the new economics of competition. Harvard Business Review, 76(6).

Propris de, L. (2002). Types of innovation and inter-firm co-operation. Entrepreneurship \& Regional Development, 14(4).

Propris de, L., Menghinello, S., \& Sugden, R. (2008). The internationalization of production systems: Embeddedness openness and governance. Entrepreneurship \& Regional Development, 20(6).

Pyke, F., \& Sengenberger, W. (1992). Industrial districts and local economic regeneration. Geneva: International Institute for Labour Affairs.

Rugraf, E. (2010). Foreign direct investment (FDI) and supplier-oriented upgrading in the Czech motor vehicle industry. Regional Studies, 44(5).

Saxenian, A. (2000). Regional networks in Silicon Valley and Route 128. In Z.J. Acs (Ed.), Regional innovation, knowledge, and global change. London-New York: Pinter.

Saxenian, A. (2007). Brain circulation and regional innovation: The Silicon Valley-Hsinchu-Shanghai triangle. In K.R. Polenske (Ed.), The economic geography of innovation. Cambridge, UK: Cambridge University Press.

Soda, G., Usai, A., \& Zaheer, A. (2004). Network memory: The influence of past and current networks on performance. Academy of Management Journal, 47(6).

Sornn-Friese, H., \& Sørensen, J.S. (2005). Linkage lock-in and regional economic development: The case of Øresund medi-tech plastics industry. Entrepreneurship \& Regional Development, 17(4).

Vanhaverbeke, W. (2001). Realizing new regional core competencies: Establishing a customer-oriented SME network. Entrepreneurship \& Regional Development, 13(2).

Wall, R.S., \& Knaap van der, G.A. (2011). Sectoral differentiation and network structure within contemporary worldwide corporate networks. Economic Geography, 87(3).

Winter, J. (2010). Upgrading of TNC subsidiaries: The case of the Polish automotive industry. International Journal of Automotive Technology and Management, 10(2-3). 